\title{
ENTOMOLOGY
}

\section{New insights on Lepidoptera of Southern Italy with description of the male of Coenotephria antonii Hausmann 2011 (Lepidoptera)}

\author{
M. Infusino, ${ }^{1}$ G. Luzzi, ${ }^{2}$ S. Scalercio ${ }^{1}$ \\ ${ }^{1}$ Consiglio per la Ricerca in Agricoltura e l'analisi dell'economia Agraria, Centro di ricerca Foreste e Legno, Rende; \\ ${ }^{2}$ Ente Parco Nazionale della Sila, Lorica di San Giovanni in Fiore, Italy
}

\begin{abstract}
Southern Italy is of particular biogeographic interest due to the location at the center of the Mediterranean Basin and its great environmental heterogeneity. Despite the faunistic interest of this territory, many insect taxa are still little investigated. Among insects, Lepidoptera have a relatively well known fauna, significantly increased in recent years, but there are still some gaps of knowledge in several habitats. The aim of this work was to contribute to the
\end{abstract}

Correspondence: Marco Infusino, Consiglio per la ricerca in agricoltura e l'analisi dell'economia agraria, Centro di ricerca Foreste e Legno (CREA-FL), c.da Li Rocchi, 87036 Rende (CS), Italy.

Tel.: +39.0984.4052247 - Fax: +39.0984.4052245

E-mail: marco.infusino@crea.gov.it

Key words: Calabria, biodiversity, relict populations, mountain areas, forests, endemism.

Acknowledgments: We are deeply indebted with Axel Hausmann for important information he provided us with. We also thank the Sila National Park, Pollino National Park and Natural Regional Park of Serre authorities for releasing us the permits for collecting.

Contributions: the authors contributed equally.

Conflict of interest: the authors declare no potential conflict of interest.

Funding: The work was financially supported by the Project "ALForLab" (PON03PE_00024_1) co-funded by the National Operational Programme for Research and Competitiveness (PON R\&C) 2007-2013, through the European Regional Development Fund (ERDF) and national resource (Revolving Fund - Cohesion Action Plan (CAP) MIUR).

Received for publication: 9 May 2017.

Accepted for publication: 11 June 2017.

CCopyright M. Infusino et al., 2017

Licensee PAGEPress, Italy

Journal of Entomological and Acarological Research 2017; 49:6783

doi:10.4081/jear:2017.6783

This article is distributed under the terms of the Creative Commons Attribution Noncommercial License (by-nc 4.0) which permits any noncommercial use, distribution, and reproduction in any medium, provided the original author(s) and source are credited. knowledge of the Macrolepidoptera of Southern Italy, focusing our study in Calabria, and to offer some thoughts on the role played by the Mediterranean mountain forests for the biodiversity conservation. Samplings were carried out in three mountainous areas of Calabria (Pollino Massif, Sila Massif and Serre Mountains) in MayNovember 2015 and in April-November 2016, using UV-LED light traps. We found ten species of high faunistic interest. Three species, Nebula senectaria, Perizoma lugdunaria and Acasis appensata, were for the first time recorded from Southern Italy, while seven were for the first time recorded from Calabria: Coenotephria antonii, Thera obeliscata, Triphosa dubitata, Trichopteryx carpinata, Asteroscopus sphinx, Lithophane semibrunnea and Sideridis reticulata. Of great interest was the discovery of the first male certainly attributable to Coenotephria antonii, endemic of Southern Italy, here described for the first time. The results exposed confirm that the fauna of Southern Italy is of great conservation value, hosting endemisms and several relict populations of European and Asiatic species with differentiated genetic lineages highly vulnerable to the climate change expected for the coming decades.

\section{Introduction}

Southern Italy is a peninsular portion of the European territory, positioned at the center of the Mediterranean Basin with a long and complicated biogeographic history. Because of its peculiar geographic position and its particular orographic and geomorphological features, this territory hosts in a relatively small space a large number of habitats very different from each other. As a consequence, this area is inhabited by a high diversity and is now considered a biodiversity hotspot (Zachos \& Habel, 2011). Although the high faunistic interest of this territory, many insect taxa are still little investigated, lacking a comprehensive study devoted to fill the gap in comparison with Central and North European countries.

Among insects, Lepidoptera have a relatively well known fauna. In fact, in the last decades there has been a significant increase of researches on Lepidoptera in the southernmost continental Italian regions, some concerning large territories (Parenzan, 1979; 1994a; Parenzan \& Scalercio, 1996; Parenzan et al., 1998; Scalercio 2014a,b), some devoted to the fauna of a given habitat (Scalercio \& Infusino, 2003, 2006; Scalercio et al., 2008; Scalercio, 2009, 2014c). However, knowledge still appears far from being exhaustive, as shown by the high number of species recently added to the regional fauna (Scalercio 2014b; Infusino et al., 2016; Infusino \& Scalercio, 2015, 2017; Infusino et al. 
2017a). In fact, at present, in Calabria the number of known species of Macrolepidoptera is approximately 1100, of which about 180 species $(16 \%)$ have been reported only in the last 20 years. This is mainly due to the lack of knowledge of some forested habitats of great biogeographic interest (Scalercio, 2014c).

In recent years, DNA barcoding has been integrated with traditional taxonomic techniques. This new biomolecular approach is a powerful tool to promote a rapid increase of biodiversity repertories (Hebert et al., 2003; Hajibabaei et al., 2006). Even well known species groups as those of processionary moths showed to be more specious than expected thanks to barcoding analyses (Trematerra et al., 2017). Some species of Lepidoptera have recently been described or recognized as valid species thanks to barcoding analysis in the studied regions: e.g. Hydriomena sanfilensis (Stauder 1915) (Hausmann \& Viidalepp, 2012), Hylaea mediterranea Sihvonen, Skou, Flamigni, Fiumi \& Hausmann 2014 (Sihvonen et al., 2014) or Nothocasis rosariae Scalercio, Infusino \& Hausmann 2016 (Scalercio et al., 2016).

Faunistic novelties, here intended as species not found before in a given geographic area, often have a great conservation value because usually correspond to isolated populations at the border of species range submitted to high abiotic stresses and/or have very small populations (Scalercio, 2009; Sommer et al., 2017). Moreover they can help to refine species distribution at small scales (subregions, provinces), and can offer new insights on the biogeographic history of a region. This is even more important for the Mediterranean mountain forests, considered biodiversity hotspots particularly sensitive to climate change due to the presence of numerous relict habitats (Myers et al., 2000; Biondi et al., 2010). Some tree species characterizing the Mediterranean mountain forests, such as Abies alba, Pinus nigra calabrica and Fagus sylvat$i c a$, gave a fundamental contribute to the definition of Natura 2000 habitats in Southern Italy (Habitats Directive 92/43/EEC) and host relict populations of several moth species (Infusino et al., 2016).

The aim of this paper is to contribute to the knowledge of the Macrolepidoptera of Southern Italy, focusing our study in Calabria, the southernmost Italian region of the peninsular territory. We also provided genetic data for some of them carrying out some considerations on their reproductive isolation and the role played by the Mediterranean mountain forests for the biodiversity conservation.

\section{Materials and methods}

This paper is focused on the most interesting faunistic findings obtained during a large moth samplings carried out in three mountainous areas of Calabria, characterized by different forest types (sensu Barbati et al., 2007). The northernmost area was the Pollino Massif, Cosenza Province, northern Calabria, characterized by a limestone substrate with karst formations. The sampling sites were located between 990 and $1475 \mathrm{~m}$ a.s.l., in an area characterized by beech forests (Fagus sylvatica L.) interspersed with pastures. The southernmost area was the Serre Mountains, Vibo Valentia province, southern Calabria, with crystalline substratum, in geomorphologic continuity with the Aspromonte Massif. It is characterized by the presence of fir forests (Abies alba Mill.), partly mixed with beeches, subject to forest management since long time. The sampling sites were located between 830 and $1100 \mathrm{~m}$ a.s.l. The third area, located between the aforementioned mountainous reliefs, was the Sila Massif, Cosenza province, with crystalline substratum, placed in the central area of the Calabria region. It is covered by extended endemic black pine forests (Pinus nigra calabrica [Loud.] Cesca \&
Peruzzi) alternated with pastures and fields. The sampling sites were positioned between 1250 and $1445 \mathrm{~m}$ a.s.l.

Moths were collected monthly using UV-LED light traps (15 W-395 nm emission peak; Infusino et al., 2017b), between May and November 2015, and April and November 2016.

Tissue samples of some specimens were submitted to the standard animal sampling procedures of the Canadian Centre for DNA Barcoding (CCDB) for sequencing the mitochondrial 5, cytochrome oxidase subunit 1 gene (COI), fragment length $658 \mathrm{bp}$, the standard utilized for the identification of animals (Hajibabaei et al., 2006). DNA Barcoding Analysis was used in order to identify endemic genetic lineages: the interspecific differences and cladograms were calculated as minimum pairwise distance using the Kimura 2 Parameter model (BOLD alignment), employing the analytical tools on Barcode of Life Data Systems (BOLD) (Ratnasingham \& Hebert, 2007). Barcode Index Number System (BINs) is an online BOLD framework that clusters barcode sequences algorithmically, generating a specific code and a web page for each cluster. Since clusters show high concordance with species, this system can be used to verify species identifications when taxonomic information is lacking (www.boldsystem.org).

\section{Results}

During the samplings we collected 61,582 individuals $(N)$ belonging to 542 species $(S)$ (Pollino-Orsomarso: $N=33,956$, $S=407$; Sila Massif: $N=18,827, S=367$. Serre Mountains: $N=8799$, $S=309$ ). Ten species of particular faunistic interest were collected. For each of them we reported: chorotype (sensu Parenzan, 1994b); collecting data (toponyms, UTM coordinates, altitude, number of specimens, date); short notes on their biology; Italian distribution (Mironov, 2003; Parenzan \& Porcelli, 2006; Hausmann \& Viidalepp, 2012) with notes on the importance of the finding; results of barcoding analyses (if available). Furthermore, we provided the first description of the male of Coenotephria antonii Hausmann, 2011 for which only two females had been known until now. All recovered sequences of the specimens submitted to barcoding analysis were $658 \mathrm{bp}$ long.

\section{Species list}

Nebula senectaria (Herrich-Schäffer 1852) - East-Mediterranean Anatolian (Figure 1a)

Pollino-Orsomarso: Timpone della Magara, Saracena. UTM: 590112.84 E - 4404524.50 N; 1,475 m a.s.1. (1 ex. - 20.V.2015); Piano del Minatore, Saracena. UTM: 591246.33 E - 4404283.67 N; 1,433 m a.s.1. (1 ex. - 06.VI.2016).

BIOLOGY: Xero-thermophilic, larva unknown (Hausmann \& Viidalep, 2012).

ItALIAN Distribution: Lazio, Abruzzi. New from Southern Italy (Figure 2a).

GENETIC DATA. BOLD codes - specimen ID: LEP-SS-00288; sequence page: BIBSA778-15; GenBank: KU497379. The species is rather homogeneous from the genetic point of view, with negligible differences compared to other specimens in BOLD (Figure 3a).

Coenotephria antonii Hausmann 2011 - South-Appenninic (Figure 1b)

Pollino-Orsomarso: Serrapaolo, Saracena. UTM: 593380.28 E $4408629.75 \mathrm{~N} ; 990 \mathrm{~m}$ a.s.1. (1 ex. - 14.X.2015). 

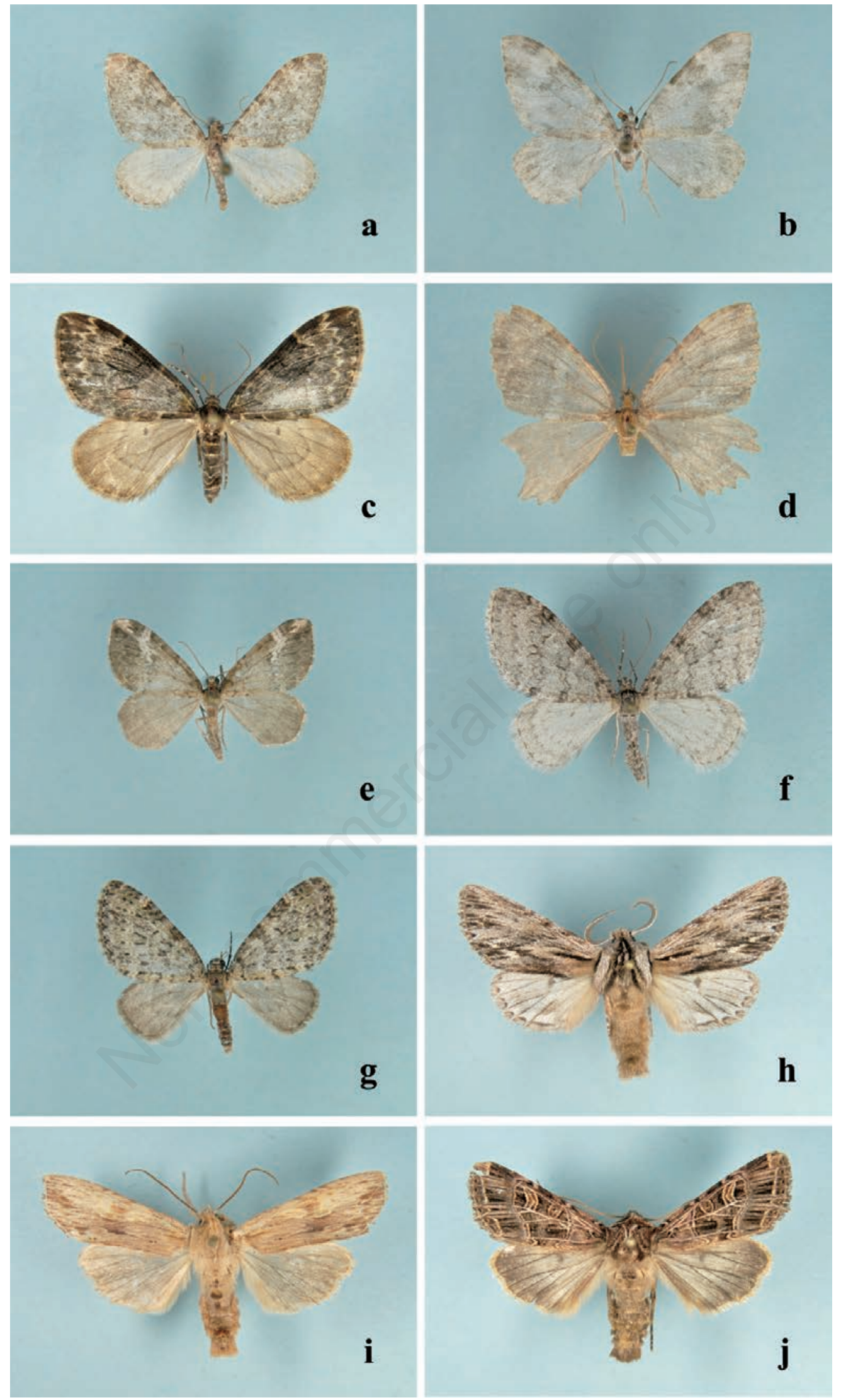

Figure 1. Habitus of the collected species (wingspan in parentheses): a) Nebula senectaria (25 mm); b) Coenotephria antonii (male Allotypus) (24 mm); c) Thera obeliscata (33 mm); d) Triphosa dubitata (34 mm); e) Perizoma lugdunaria (19 mm); f) Trichopteryx carpinata (30 mm); g) Acasis appensata $(21 \mathrm{~mm}) ; \mathrm{h})$ Asteroscopus sphinx (40 mm); i) Lithophane semibrunnea (42 mm); j) Sideridis reticulata $(38 \mathrm{~mm})$. 
BIOLOGY. Xerophilous species. Larva unknown (Hausmann \& Viidalepp, 2012). It seems to prefer forested habitats.

ITALIAN Distribution: Abruzzi (dubious), Basilicata. New from Calabria, second locality known with certitude and first male known to science (Figure $2 b$ ).

GENETIC DATA. BOLD codes - specimen ID: LEP-SS-00399; sequence page: BIBSA1653-16.

The species, which has recently been described, is a very rare nearly punctiform endemism of Southern Italy. The species was initially described as a vicariant of Coenotephra tophaceata (Denis \& Schiffermüller, 1775) in Central and Southern Italy, but later both species were found to occur sympatrically (Scalercio et al., 2014). Another specimen from Abruzzi is tentatively attributed to this species (A. Hausmann, pers. com.), but it shows a significant genetic distance $(3.85 \%)$ and its taxonomic status should presumably be reviewed. The specimen from Abruzzi, in fact, has a BIN different (BOLD: ACL7300) from those of the typical C. antonii (BOLD: ADB7125). The specimens from Calabria and Basilicata diverge genetically by the $0.27 \%$, suggesting a preliminary intraspecific genetic diversity.

This is the third specimen known to science and the first male certainly attributable to this species here regarded as an allotypus. After further taxonomic investigations, the male described in Hausmann \& Viidalepp (2012) has been identified as belonging to C. tophaceata (A. Hausmann, pers. com.).

\section{Description of the allotypus}

EXTERnAl CHARACTERS. Wingspan $24 \mathrm{~mm}$. Ground colour greywhitish. Wing pattern similar to those of C. tophaceata, but paler, not well-defined and without yellow coloration. Forewings whit pale grey medial and basal area. Hindwings with slightly darker grey terminal area. Antennae filiform, setose.

Male Genitalia. Valva oblong, of constant breadth and with rounded apex. Long labides with the distal portion hooked. Uncus long and narrow, triangularly shaped at the base. Fallus curved, relatively short and wide (Figure 4a).
SIMILAR SPECIES. As well as for the female (Hausmann, 2011), the male of this species is very similar to C. tophaceata, from which it differs for the less defined pattern, the lighter coloration and the absence of yellow shades. Genitalia with valva not dilated distally. The base of the uncus is triangular, regularly shaped, while those of C. tophaceata showing basal protuberances (Figures 4 and 5).

Thera obeliscata (Linnaeus 1758) - Euro-Siberian Caucasian (Figure 1c)

Serre Mountains: Santa Maria, Serra San Bruno. UTM: 613529.96 E - 4267239.38 N; 925 m a.s.1. (1 ex. - 06.IV.2016).

Biology. Sylviculous species. The larva is reported as monophagous on Pinus sylvestris, but probably feeds also on other conifers (Hausmann \& Viidalepp, 2012).

ItALiAn Distribution: Aosta Valley, Piedmont, Lombardy, Trentino-South Tyrol, Veneto, Liguria, Abruzzi, Basilicata. New from Calabria (Figure 2c).

GENETIC DATA. BOLD codes - specimen ID: LEP-SS-00534; sequence page: BCLEP084-16. The barcoding analisys showed a very complex taxonomic framework for the Thera species group. Probably the difficulty in distinguishing the species of this group, may have caused erroneous identifications in BOLD, making hard the reading of clusters. The Calabrian specimen of T. obeliscata seems to belong to a separate lineage from the other European specimens, but the distance to the nearest sequence from a South France specimen is only of the $0.68 \%$ (Figure 3b).

Triphosa dubitata (Linnaeus 1758) - Eurasiatic (Figure 1d) Pollino-Orsomarso: Serrapaolo, Saracena. UTM: 593380.28 E 4408629.75 N; $990 \mathrm{~m}$ a.s.1. (1 ex. - 24.VIII.2015).

Bıology. Sylviculous species, with trogophile habits. Larva oligophagous on Rhamnus spp., Prunus spp., Fraxinus spp., Frangula alnus (Hausmann \& Viidalepp, 2012).

ITALIAN DISTRIBUtion: Aosta Valley, Piedmont, Lombardy,

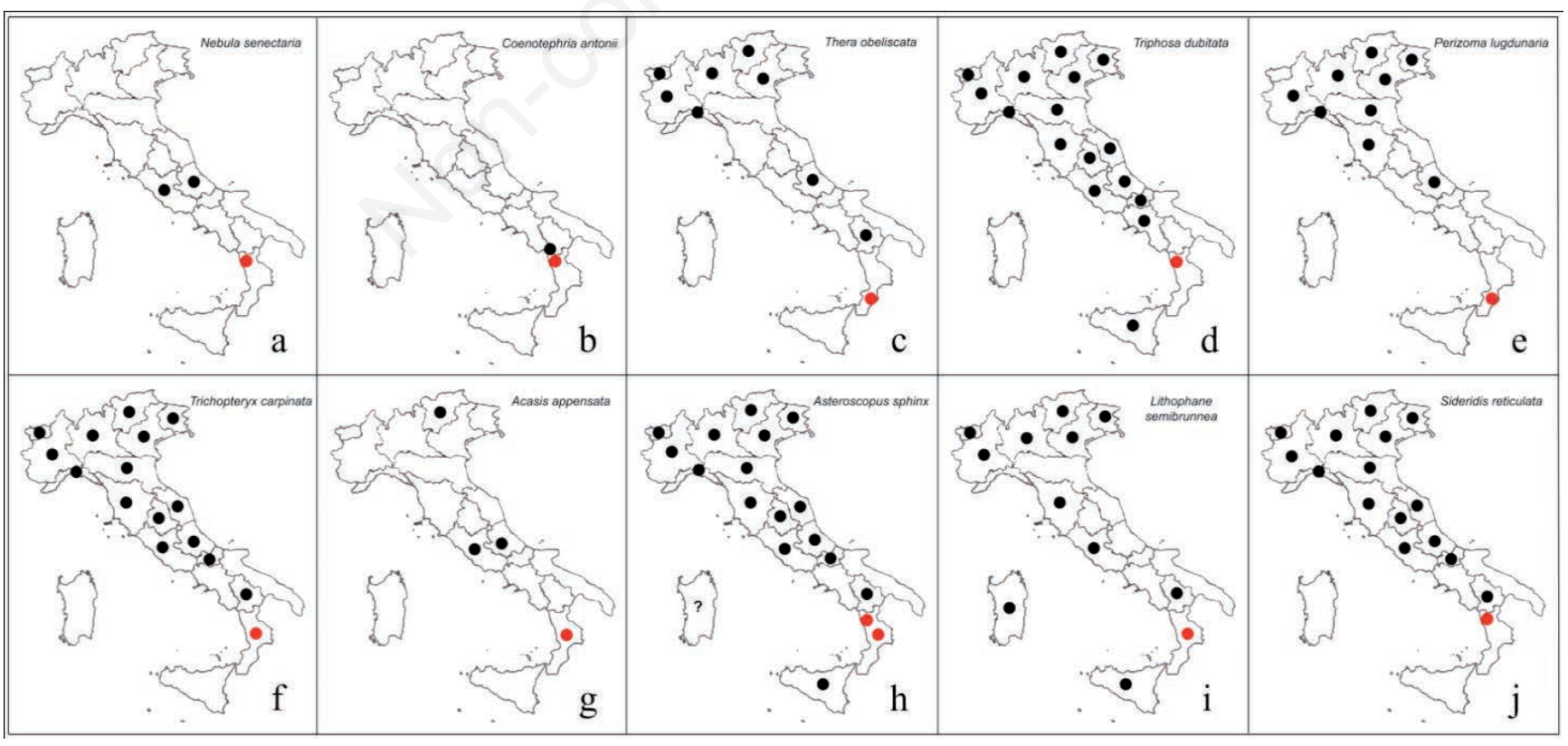

Figure 2. a,j) Regional presence in Italy of species covered in this paper derived from literature. Red points represent the new localities in Southern Italy. In b) the black point indicates the locus typicus of Coenotephria antonii in order to highlight the proximity of this locality in Basilicata to the new one in Calabria. 
Trentino-South Tyrol, Veneto, Friuli-Venezia Giulia, Liguria, Emilia-Romagna, Tuscany, Umbria, Marche, Lazio, Abruzzi, Molise, Campania, Sicily. New from Calabria (Figure 2d).

GeNeTIC DATA. BOLD codes - specimen ID: LEP-SS-00411; sequence page: BIBSA1681-16. The species is rather homogeneous from a genetic point of view but the Calabrian and Sicilian specimens form a cluster separated from those of Central Europe (minimum distance: $0.51 \%$ ) (Figure $3 \mathrm{c}$ ).

Perizoma lugdunaria (Herrich-Schäffer 1855) - European (Figure 1e) Serre Mountains: Palmento, Serra San Bruno. UTM: 614499.70 E - 4269051.60 N; $831 \mathrm{~m}$ a.s.1. (1 ex. - 03.VIII.2016).

Biology. The species is linked to meso-hygrophilous forested habitats. Larva monophagous on Cucubalus baccifer (Mironov, 2003).
Italian distribution: Piedmont, Lombardy, Trentino-South Tyrol, Lazio, Molise. New from Southern Italy (Figure 2e).

Genetic data not available.

Trichopteryx carpinata (Borkhausen 1794) - Euro-Siberian (Figure 1f)

SILA Massif: Montagna Grande, San Giovanni in Fiore. UTM: 638895.15 E - 4348709.71 N; 1,352 m a.s.l. (8 exx.); Montagna Grande. UTM: 639189.07 E - 4349312.45 N; 1,325 m a.s.1. (2 exx.); Montagna Grande. UTM: 638566.08 E - 4348166.12 N; 1,344 m a.s.1. (1 ex.); Mangiatoie. UTM: 643479.36 E - 4344626.99 N; 1,275 m a.s.1. (1ex.); Mangiatoie. UTM: 643672.77 E - $4344502.67 \mathrm{~N}$; 1,270 m a.s.1. (1ex.) (all collected on 12.IV.2016); Sbanditi. 637980, $01 \mathrm{E}-4361157.15 \mathrm{~N} ; 1,340 \mathrm{~m}$ a.s.1. (1 ex. -04.V.2015).

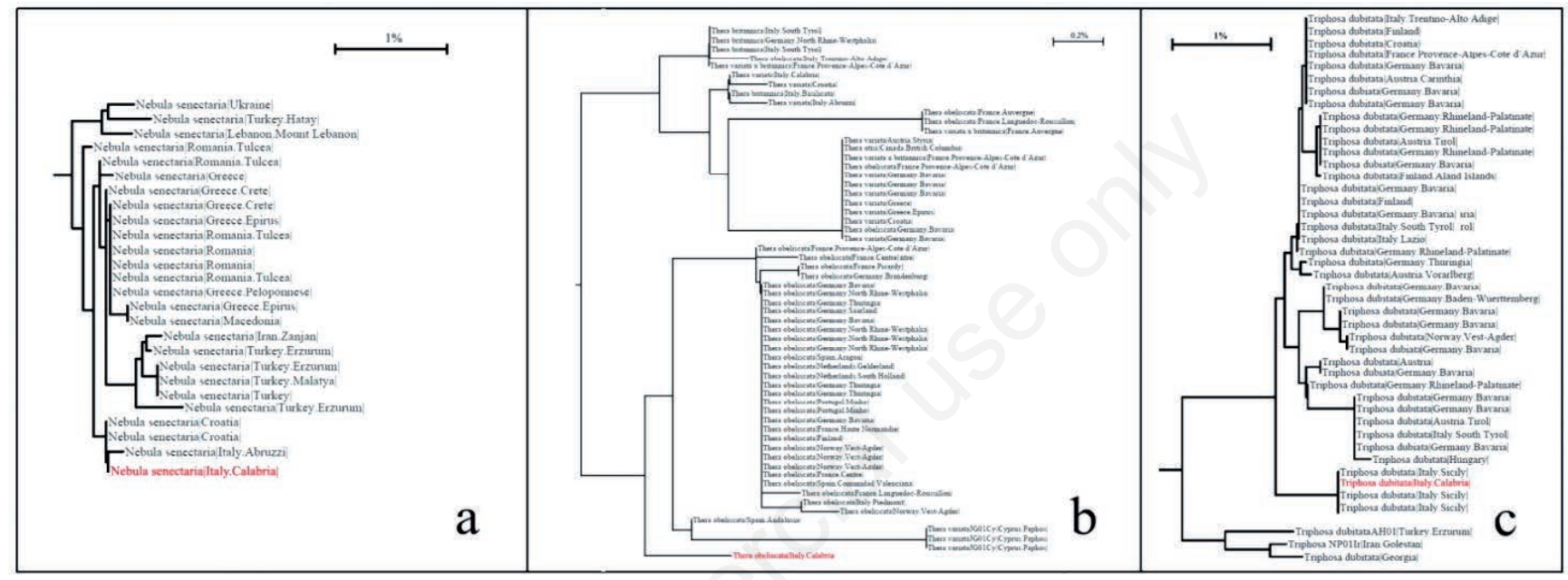

Figure 3. Neighbor joining trees (Kimura 2-parameter distance model for COI-5P marker) of species covered in this paper built using sequences deposited in BOLD. a) Nebula senectaria, b) Thera obeliscata, c) Thiphosa dubitata. In red the specimens subjected to barcoding analysis in this study.

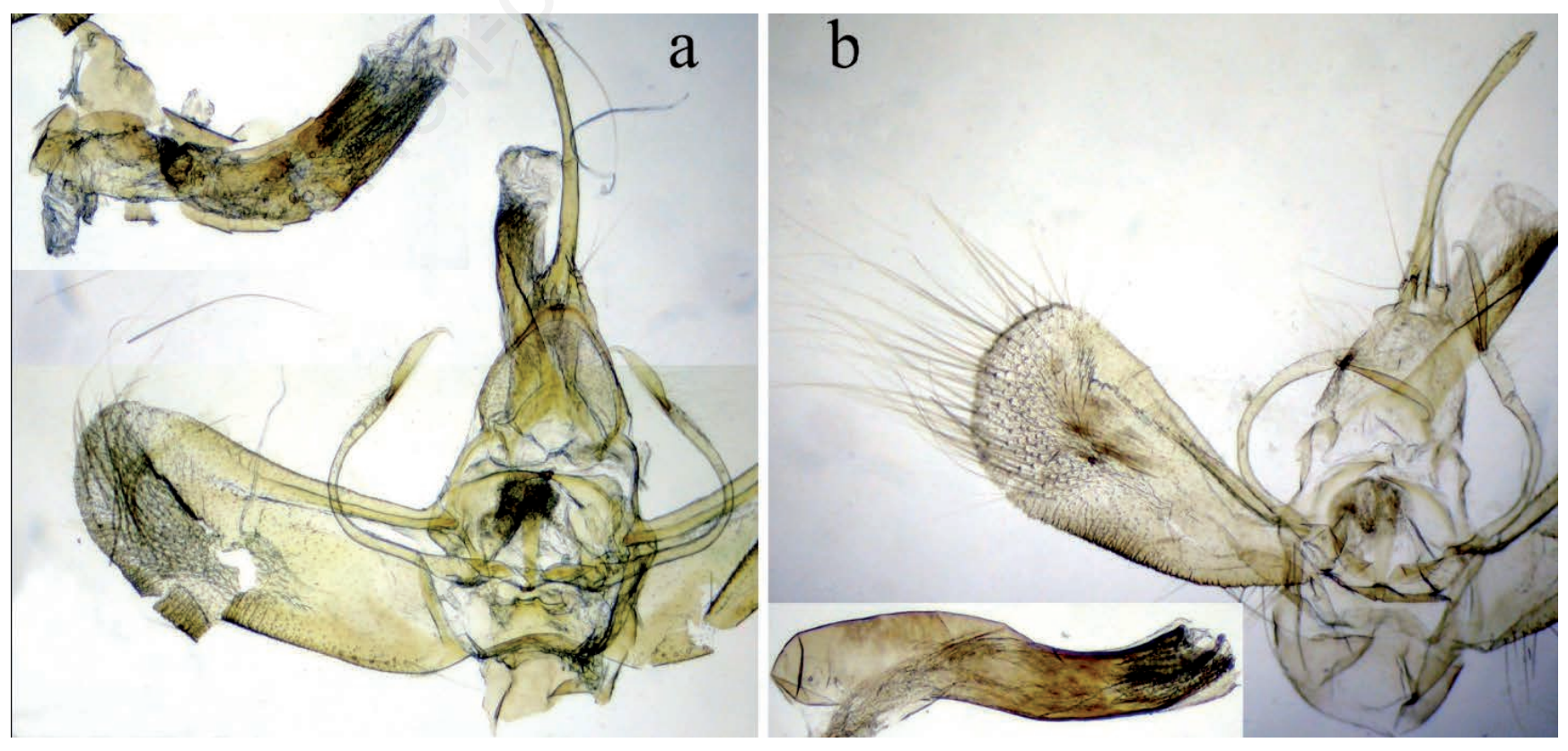

Figure 4. Male genitalia (phallus separated) of: a) Coenotephria antonii; b) Coenothephria tophaceata. 
BIOLOGY. The species inhabits meso-hygrophilous forests. Larva feeds on various Betulaceae and Salicaceae (Hausmann \& Viidalepp, 2012).

ITALiAn Distribution: Aosta Valley, Piedmont, Lombardy,Veneto, Trentino-South Tyrol, Friuli-Venezia Giulia, Liguria, EmiliaRomagna, Tuscany, Marche, Umbria, Lazio, Abruzzi, Molise, Basilicata. New from Calabria (Figure 2f).

GENETIC DATA. BOLD codes - specimen ID: LEP-SS-00531; sequence page: BCLEP081-16. The Calabrian specimen in BOLD is placed in a separate cluster at a distance of the $0.76 \%$ from the nearest neighbor (Figure 6a).

Acasis appensata (Eversmann 1842) - Eurasiatic (Figure 1g) SIla MASSIF: Mangiatoie, San Giovanni in Fiore. UTM: 643585.92 E - 4344384.53 N; 1,275 m a.s.1. (1 ex. - 11.V.2016).

Biology. Sylviculous species. Larva monophagous on Actaea spp. (Hausmann \& Viidalepp, 2012).

ITALIAN DISTRIBUTION: Trentino-South Tyrol, Lazio and Abruzzi (Terminillo Mount) as A. appensata callaina Hausmann \& Huemer 2011. New from Southern Italy (Figure $2 \mathrm{~g}$ ).

GENETIC DATA. BOLD codes - specimen ID: LEP-SS- 00532; sequence page: BCLEP082-16. The genetic context is very interesting. The Calabrian specimen forms a separate cluster along with the specimens from Central Italy, considered as belonging to the endemic subspecies A appensata callaina (Hausmann \& Huemer, 2011). This cluster shows the minimum distance (1.38\%) with the North American populations of a congeneric species (A. viridata) which, according to Hausmann \& Huemer (2011), should be downgraded to subspecies of $A$. appensata. Moreover, the Calabrian specimen of $A$. appensata diverges from $A$. appensata callaina by the $1.99 \%$, and from the European specimens of $A$. appensata appensata by the $3.98 \%$. The taxonomic position of the Calabrian A. appensata is, therefore, far from clear and certainly deserves deeper analysis based on a sample larger than one specimen (Figure 6b).

Asteroscopus sphinx (Hufnagel 1766) - Euro-Anatolian (Figure 1h)

Pollino-Orsomarso: Serrapaolo, Saracena. UTM: 593380.28 E 4408629.75 N; 990 m a.s.l. (1 ex. - 18.XI.2015); Serrapaolo. UTM: 593145.98 E- $4408625.88 \mathrm{~N} ; 1,010 \mathrm{~m}$ a.s.1. (2 exx. - 18.XI.2015).
SILA Massif: Montagna Grande, San Giovanni in Fiore. UTM: 638895.15 E - 4348709.71N; 1,352 m a.s.1. (1 ex. - 07.XI.2016); Montagna Grande. UTM: 638566.08 E - 4348166.12 N; 1,344 m a.s.1. (22 exx. - 04.XI.2015; 1 ex. - 07.XI.2016); Mangiatoie. UTM: 643585.92 E - 4344384.53 N; 1,75 m a.s.1. (1 ex. - 07.XI.2016).

BIology. The species inhabits forested environments. Larva polyphagous on many deciduous trees (Hellmann \& Parenzan, 2010).

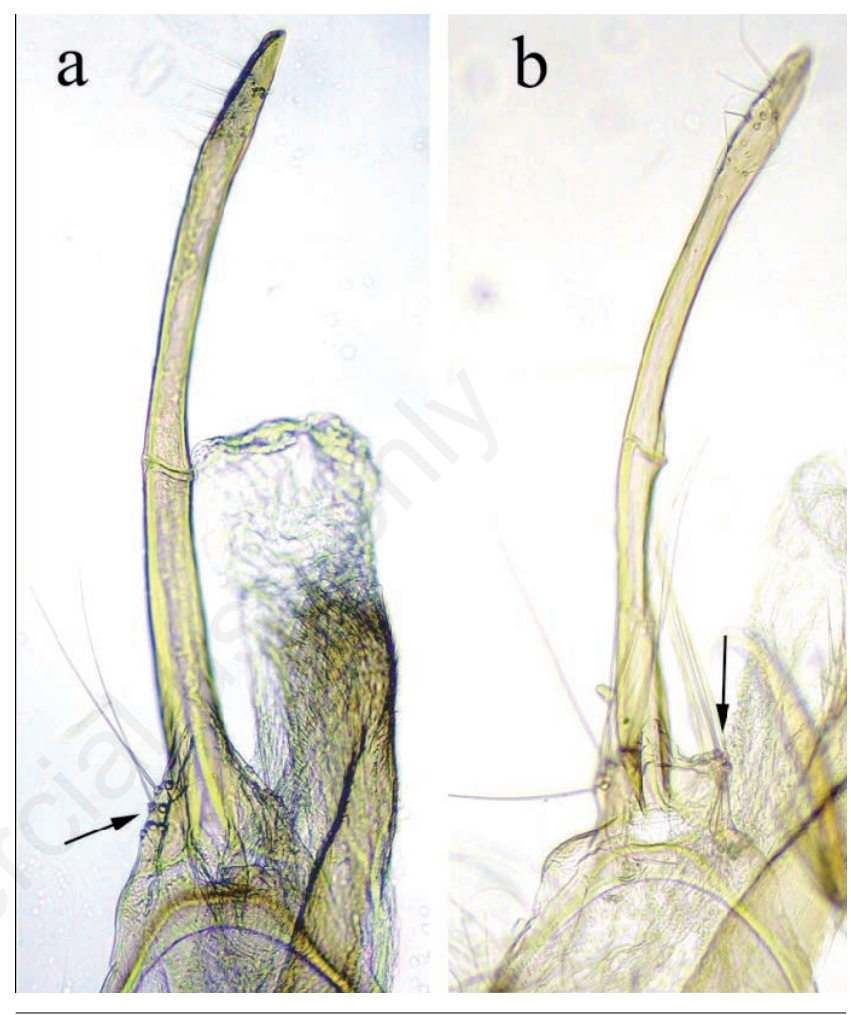

Figure 5. Detail of uncus: a. Coenotephria antonii, b. Coenothephria tophaceata. The arrows indicate the diagnostic character at the base of the uncus.

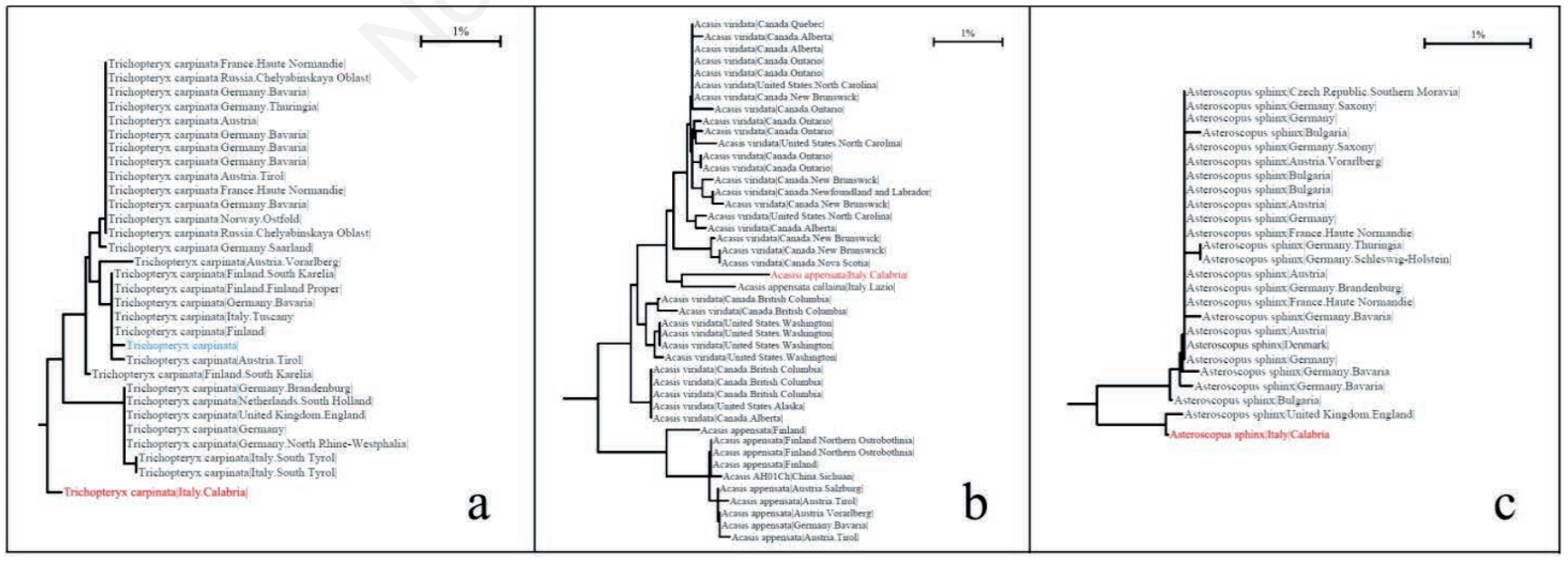

Figure 6. Neighbor joining trees (Kimura 2-parameter distance model for COI-5P marker) of species covered in this paper built using sequences deposited in BOLD. a) Tricopterix. carpinata, b) Acasis appensata, c) Asteroscopus sphinx. In red the specimens subjected to barcoding analysis in this study. a) In blue a specimen which geographical origin is unknown. 
ITALIAN DISTRIBUTION: Aosta Valley, Piedmont, Lombardy,Veneto, Trentino-South Tyrol, Friuli-Venezia Giulia, Liguria, EmiliaRomagna, Tuscany, Marche, Umbria, Lazio, Abruzzi, Molise, Basilicata, dubious for Sardinia. New from Calabria (Figure 2h). GENETIC DATA. BOLD codes - specimen ID: LEP-SS- 00424; sequence page: BIBSA1686-16. The Calabrian specimen belongs to a separate cluster compared to the specimens of continental Europe (minimum distance: $1.22 \%$ ). In the same cluster there is a specimen from England, which suggests that the distribution of the haplotypes in the populations is not linked to geographical patterns (Figure 6c).

Lithophane semibrunnea (Haworth 1809) - Euro-Mediterranean Atlantic (Figure 1i)

SILA MaSSIF: Mangiatoie, San Giovanni in Fiore. UTM: 643585.92 E - 4344384.53 N; 1,275 m a.s.1. (1 ex. - 12.IV.2016); Montagna Grande. UTM: 638566.08 E - 4348166.12 N; 1,344 m a.s.l. (1 ex. - 11.V.2016).

Biology. Species linked to humid forest habitats. Larva feeds on some broad-leaved such as Betula spp., Fraxinus spp., Ligustrum spp., Prunus spp. and Quercus spp. (Hellmann \& Parenzan, 2010). ItALiAn Distribution: Aosta Valley, Piedmont, Lombardy,Veneto, Trentino-South Tyrol, Friuli-Venezia Giulia, Tuscany, Lazio, Basilicata, Sicily, Sardinia. New from Calabria (Figure 2i).

Genetic data not available.

Sideridis (Heliophobus) reticulata (Goeze 1781) - EuroAnatolian (Figure 1j)

Pollino-Orsomarso: Piano del Minatore, Saracena. UTM: 591288.84 E - 4404168.60 N; 1,419 m a.s.1. (1 ex. - 30.VI.2016).

Biology. Xero-thermophilic species, linked to open herbaceus formations. Larva polyphagous on a large number of herbaceous plants (Hellmann \& Parenzan, 2010).

ITALIAN DistRibution: Aosta Valley, Piedmont, Lombardy,Veneto, Trentino- South Tyrol, Friuli-Venezia Giulia, Liguria, EmiliaRomagna, Tuscany, Marche, Umbria, Lazio, Abruzzi, Molise, Basilicata. New from Calabria (Figure 4j).

Genetic data not available.

\section{Discussion and conclusions}

We listed ten species of relevant faunistic interest among which the most important are Nebula senectaria, Perizoma lugdunaria and Acasis appensata, all recorded for the first time from Southern Italy. The previous lack of records for these species and for Triphosa dubitata and Sideridis reticulata could be due to the presence of only small and isolated populations in the study area. The remaining species were undiscovered until now probably because of the paucity of faunistic researches during the whole flight season of moths. In fact, Trichopteryx carpinata, Thera obeliscata and Lithophane semibrunnea are on wings in early spring and Asteroscopus sphinx and Coenotephria antonii, a very rare endemism of southern Italy, in late autumn.

Of great taxonomic interest was the first discovery of a male of Coenotephria antonii, here described for the first time, that allowed us to link the large genetic difference from the congeneric C. tophaceata $(5.72 \%)$ to evident morphologic differences in their genitalia. This finding could help to define the taxonomic status of a Coenotephria specimen found in the Abruzzi that had been putatively attributed to $C$. antonii until now, despite it belongs to a different BIN according to barcoding analyses.

Because of the great differences in latitude between the two extremities of the Italian peninsula, many of these species are common also at low altitude in Central Europe and Northern Italy and become rarer and more linked to mountainous habitat southward, where their populations are often fragmented (Mironov, 2003; Hellmann \& Parenzan, 2010; Hausmann \& Viidalepp, 2012). The populations of $N$. senectaria, T. obeliscata, P. lugdunaria, $A$. appensata and L. semibrunnea, for example, are isolated from the core of the species range, even of hundreds kilometers (Figure 4). Genetic analyses provided further data that confirmed the key role played by Southern Italy, especially mountainous areas, for the conservation of diversity. In fact, Calabrian specimens of three species (T. dubitata, T. carpinata, A. appensata) have been proved to show endemic genetic lineages (Figures 3 and 6). In addition, the high genetic distance of the Calabrian A. appensata from known populations of the same species suggests a reassessment of its taxonomic status, even if this would require further data.

Nebula senectaria of the Pollino Massif showed a low divergence from the European lineages despite the large, but probably recent, isolation of this population. This is presumably due to the biogeographic history of $N$. senectaria, with Eastern Mediterranean range, that differs from those having large genetic divergence, usually with the range centered in Central Europe.

The results exposed, along with latest important faunistic discoveries (Scalercio, 2014a; Infusino et al., 2016, 2017b; Infusino \& Scalercio, 2017), confirm that Southern Italy has a territory with high diversity and depositary of several relict populations of species having northern range, some of which with endemic genetic lineages. This represents a remarkable portion of biodiversity highly vulnerable to the climate change expected for the coming decades.

\section{References}

BARBATI A., CORONA P., MARCHETTI M., 2007 - A forest typology for monitoring sustainable forest ecosystem management: the case of European Forest Types. - Plant Biosyst. 1: 93-103.

BIONDI E., BLASI C., BURRASCANO S., CASAVECCHIA S., COPIZ R., DEL VICO E., GALDENZI D., GIGANTE D., LASEN C., SPAMPINATO G., VENANZONI R., ZIVKOVIC L., 2010 - Manuale italiano di interpretazione degli habitat (Direttiva 92/43/CEE).- Ministero dell'Ambiente e della Tutela del Territorio e del Mare, Roma, Italy.

HAJIBABAEI M., JANZEN D.H., BURNS J.M., HALLWACHS W., HEBERT P.D.N., 2006 - DNA barcodes distinguish species of tropical Lepidoptera. - Proc. Natl. Acad. Sci. USA 103: 968971.

HAUSMANN A., 2011 - An integrative taxonomic approach to resolving some difficult questions in the Larentiinae of the Mediterranean region (Lepidoptera, Geometridae). - Mitt. Münch. Ent. Ges. 101: 73-97.

HAUSMANN A., HUEMER P., 2011 - Taxonomic decision as a compromise: Acasis appensata (Eversmann, 1832) in Central Italy: a case of conflicting evidence between DNA barcode and morphology (Lepidoptera: Geometridae). - Zootaxa 3070: 60-68.

HAUSMANN A., VIIDALEPP J., 2012 - Larentiinae I (Perizomini and Eupitheciini). - In: HAUSMANN A. (ed.). The geometrid moths of Europe. Vol. 3. - Apollo Books, Stenstrup: 743 pp.

HEBERT P.D., CYWINSKA A., BALL S.L., 2003 - Biological identifications through DNA barcodes. Proc. R. Soc. Lond. B: Biol. Sci. 270: 313-321.

HELLMANN F., PARENZAN P., 2010 - I macrolepidotteri del 
Piemonte. Museo regionale di scienze naturali. - Franco Andreone Ed., Torino: 1060 pp.

INFUSINO M., SCALERCIO S., 2015- Eupithecia conterminata (Lienig, 1846), una specie silvicola alloctona nuova per la fauna italiana nel Parco Nazionale della Sila, area MAB Unesco (Lepidoptera, Geometridae). - Boll. Soc. Entomol. Ital. 147: 85-88.

INFUSINO M., SCALERCIO S., 2017 - The Macrolepidoptera Heterocera of silver fir woodlands in the Serre Mountains (Calabria, Italy). In: ZILLI A. (ed.), Lepidoptera italica Vol. 2. Natura Edizioni Scientifiche, Bologna: in press.

INFUSINO M., GRECO S., TURCO R., BERNARDINI V., SCALERCIO S., 2016 - Managed mountain forests as diversity reservoirs in Mediterranean landscapes: new data on endemic species and faunistic novelties of moths. - B. Insectol. 69: 249-258.

INFUSINO M., BREHM G., DI MARCO C., SCALERCIO S., 2017a - Assessing the efficiency of UV LEDs as light sources for macro-moth diversity sampling. - Eur. J. Entomol. 114: 25-33.

INFUSINO M., LUZZI G., SCALERCIO S., 2017b - I macrolepidotteri notturni dell'Arboreto Sbanditi, Area MAB-UNESCO, Parco Nazionale della Sila (Calabria, Italia). - Boll. Soc. Entomol. Ital. [in press].

MIRONOV L., 2003 - Larentiinae II (Perizomini and Eupitheciini). - In: HAUSMANN A (ed.). The geometrid moths of Europe. Vol. 4. - Apollo Books, Stenstrup: 464 pp.

MYERS N., MITTERMEIER R. A., MITTERMEIER C.G., DA FONSECA G.A., KENT J., 2000 - Biodiversity hotspots for conservation priorities. - Nature 403: 853-858.

PARENZAN P., 1979 - Contributi alla conoscenza della Lepidotterofauna dell'Italia Meridionale. V. Heterocera: Noctuidae. - Entomologica 25: 159-278.

PARENZAN P., 1994a - Contributi alla conoscenza della Lepidotterofauna dell'Italia meridionale. XVII. Heterocera: Geometridae. - Entomologica 28: 99-246

PARENZAN P., 1994b - Proposta di una codificazione per una gestione informatica dei corotipi W-paleartici con particolare riferimento alla fauna italiana. - Entomologica 28: 93-98.

PARENZAN P., PORCELLI F., 2006 - I macrolepidotteri italiani. Fauna Lepidopterorum Italiae (Macrolepidoptera). Phytophaga 15: 1-1051.

PARENZAN P., SCALERCIO S., 1996 - Nuove segnalazioni di Nottuidi (Lepidoptera) per l'Italia meridionale. (Contributi alla conoscenza della Lepidotterofauna dell'Italia meridionale. XIX). - Entomologica 30: 105-133.

PARENZAN P., HAUSMANN A., SCALERCIO S., 1998 Addenda e corrigenda ai Geometridae dell'Italia meridionale (Contributi alla conoscenza della Lepidotterofauna dell'Italia meridionale. XX). - Entomologica 32: 51-79.

RATNASINGHAM S., HEBERT P.D.N., 2007 - BOLD: The Barcode of Life Data System (www.barcodinglife.org). - Mol. Ecol. Notes 7: 355-364.
SCALERCIO S., 2009 - On top of Mediterranean Massif: climate change and conservation of orophilus moths at the southern boundary of their range (Lepidoptera: Macroheterocera). - Eur. J. Entomol. 106: 231-239.

SCALERCIO S., 2014a - New distributional data of butterflies in the middle of the Mediterranean Basin: an area very sensitive to expected climate change. Dataset Papers Science 2014: 8.

SCALERCIO S., 2014b - Nuovi dati di distribuzione dei macrolepidotteri eteroceri della fauna calabrese (Insecta Lepidoptera). - Mem. Soc. Entomol. Ital. 91: 3-59.

SCALERCIO S., 2014c - Moth diversity of a reforested site at Monte Cocuzzo (Calabria, Southern Italy). In: ZILLI A. ed., Lepidoptera research in areas with high biodiversity potential in Italy, Volume 1. - Natura Edizioni Scientifiche, Bologna: 295-317.

SCALERCIO S., INFUSINO M., 2003 - I Macrolepidotteri di Fosso Scuotrapiti, lago dell'Angitola (Calabria, Italia meridionale) (Lepidoptera). - Phytophaga 13: 25-52.

SCALERCIO S., INFUSINO M., 2006 - I Macrolepidotteri notturni del Basso corso della Fiumara Trionto (Calabria, Italia meridionale) (Lepidoptera). - Quad. Staz. Ecol. Civ. Mus. St. Nat. Ferrara 16: 181-204.

SCALERCIO S., INFUSINO M., HAUSMANN A., 2014 Advances in the knowledge of the larentiine fauna of southern Italy by DNA barcoding (Lepidoptera, Geometridae). Spixiana 37: 260.

SCALERCIO S., INFUSINO M., HAUSMANN A., 2016 - A new species of the genus Nothocasis Prout, 1937, N. rosariae sp.n., from forested habitats of southern Europe (Lepidoptera, Geometridae, Larentiinae). - Zootaxa 4161: 177-192.

SCALERCIO S., INFUSINO M., TUSCANO J., 2008 - I macrolepidotteri notturni della faggeta di Monte Curcio, Sila Grande (Calabria, Italia meridionale) (Lepidoptera). - Quad. Staz. Ecol. Civ. Mus. St. Nat. Ferrara 18: 5-19.

SIHVONEN P., SKOU P., FLAMIGNI C., FIUMI G., HAUSMANN A., 2014 - Revision of the Hylaea fasciaria (Linnaeus, 1758) species group in the western Palaearctic (Lepidoptera: Geometridae, Ennominae). - Zootaxa 3768: 469-486.

SOMMER B., BEGER M., HARRISON P.L., BABCOCK R.C., PANDOLFI J.M., 2017 - Differential response to abiotic stress controls species distributions at biogeographic transition zones. - Ecography doi: 10.1111/ecog.02986

TREMATERRA P., SCALERCIO S., COLACCI M., 2017 Thaumetopaea hellenica sp.n. and Thaumetopoea mediterranea sp.n. new taxa from Southern Europe (Lepidoptera Notontidae Thaumetopoeinae). - Redia 100: 3-10.

ZACHOS F.E., HABEL J.C. (Eds.), 2011 - Biodiversity hotspots: distribution and protection of conservation priority areas. Springer Science \& Business Media, Heidelberg: 546 pp. 